\section{Sciendo}

DANIEL SOBCZYŃSKI, IZABELA KARSZNIA

University of Warsaw, Faculty of Geography and Regional Studies

Department of Geoinformatics, Cartography and Remote Sensing

Warsaw, Poland

d.sobczynski@student.uw.edu.pl; i.karsznia@uw.edu.pl

orcid.org/0000-0001-5510-8770
Polish Cartographical Review

Vol. 51, 2019, no. 2, pp. 81-94

DOI: $10.2478 /$ pcr-2019-0007

Received: 20.11 .2018

Accepted: 06.05.2019

\title{
Landscape evolution in the area of Kazimierski Landscape Park
}

\begin{abstract}
The presented research concerning the landscape evolution of the area of the Kazimierski Landscape Park assumed the analysis of landscape changes that took place in the western part of the Nałęczów Plateau in eastern Poland as a result of increased anthropopressure. To achieve this goal, the diverse data was employed: archives of the "Archeological Survey of Poland" obtained from the National Heritage Board of Poland , the registry data from the 16th century made available as part of the "Atlas Fontium" project elaborated by the Institute of History of the Polish Academy of Sciences, old map of the Western Galicia from 1808, a tactical map of the Military Geographical Institute in Warsaw from 1937, and the "Topographic Objects Database" (BDOT10k) obtained from the Head Office of Geodesy and Cartography. Based on the analysed data, maps presenting the development of the settlement network from the moment of permanent settlement of the area up to the present state and maps showing the changes in land use in the Kazimierski Landscape Park over the last centuries have been designed.

The results of historical and geographical analyses carried out as part of the research were compared with the results of geomorphological research conducted in the studied area. Verification of the obtained results allowed to determine the scope in which man influenced the evolution of the landscape of the analysed area, including its diversification depending on the historical period and the type of the economy. The process of georeferencing the map of Western Galicia elaborated by colonel A.M. von Heldensfeld from 1808 and the tactical map 1:100,000 of Military Geographical Institute from 1937 covering the research area (14,974 ha) was carried out in the ArcGIS Desktop software. The calibration process was evaluated in the Map Analyst program which makes it possible to analyze the distortions of old maps. Then, vectorization of selected terrain coverage classes and visualization of spatial data were conducted. This way, the land use maps were analyzed in terms of environmental changes that occurred over the past centuries by identifying the areas with the largest development changes. The obtained results were compared with the database of historical objects created for the purposes of this research, based on data provided by the National Heritage Board of Poland and the Institute of History of the Polish Academy of Sciences in order to determine the development trends of the settlement network in the region. The additional statistical analysis made it possible to determine the trend of changes and to interpret the distribution of areas threatened by the occurrence of mass movements with the analyzed anthropogenic determinants.
\end{abstract}

Keywords: Geographic Information Systems, historical geography, old maps, landscape evolution

\section{Introduction}

Varied land relief of early settled loess uplands has long attracted attention of natural scientists. Rich history of the region resulting from continuous settlement on fertile, loess-based soils has also been exceptionally attractive for research in the area of humanities. Development of Nałęczów Plateau has been a subject of both archeological and geomorphological research.
This research determined the chronology of development of erosive-denudational forms in the form of dry valleys creating vast valley systems which are characteristic of the region. However, the scale of impact of prehistoric communities on the pace and direction of evolution of loess landscape remains less known. What is more neither the in-depth research in the area of Kazimierski Landscape Park has been conducted to evaluate the scale of in- 
fluence of anthropogenic factor on landscape nor the attempts have been made at its cartographic visualization. This paper aims to fill in this gap. Application of geoinformational methods in the analysis allows to differentiate subsequent stages of development and simultaneously grasp structural changes in the analyzed region over the last few centuries. Presented research also reflects the current turn towards constant monitoring of land use in the areas of natural and cultural merit. This is meant to allow control over current changes and give the public access to spatial information.

\section{Research scope and objectives}

The main objective was to recreate the evolution of landscape, through reconstruction of the network of settlement from the Paleolithic until the Middle Ages, as well as the analysis and visualization of the trends of changes in land use in Kazimierski Landscape Park. The area of research covers 14,974 ha of park area (without the buffer zone). The analysis helped to collect varied input data which made it possible to determine tendencies of changes in the natural environment in Kazimierski Landscape Park. The analyses have the added value of integrating various types of data in Geographic Information Systems (GIS). Archival data, old maps as well as various contemporary vector data were used. Application of geoinformation methods determined the range of analysis, which also covered establishing the areas characterized by biggest human influence on the natural environment. As a result the potential of GIS in geographical and historical analysis of a valuable natural protected area was shown.

\section{Concepts of landscape evolution}

Landscape is one of the first terms used in geography. For the purpose of this research the following definition was adopted: "historically shaped part of geographic space, created as a result of combined environmental and cultural impact, forming a specific structure characterized by regional distinctness perceived as a certain physiognomy" (after U. Myga-Piątek 2001 , p. 165). In the discussed subject an important role is played by the resultant character of landscape defined that way, which reflects changes in the system of perception of the environment by given settler groups. Thus U. Myga-Piątek defines landscape evolution factors as a set of natural processes varying in time and space as well as organized anthropogenic activity (U. Myga-Piątek 2012).

The concept of stages of cultural development which requires multi-dimensional analysis is also connected to the evolution of landscape. Here a special role is played by old maps they make it possible to grasp subsequent stages of landscape evolution. Changes in land cover over last centuries can be researched thanks to preserved cartographic materials. It is the analysis of historical development of landscape which is now the starting point for solving contemporary ecological problems.

By performing historical analyses J. Plit (2016, p. 14) made "an attempt to recreate stages of settlement and development of particular lands, of emergence and definition of cultural landscapes and their evolution". Whereas K. Ostaszewska et al. (2011) paid special attention to loess landscapes in relation to the significance of land use in landscape-forming processes. This is connected to high vulnerability of loess plateaus to be shaped by precipitation which leads to linear erosion, and consequently leads to the emergence of complex ravine systems. Man's impact on the state of land cover was therefore one of the main factors of evolution of landscape in loess areas. Work of S. Kukawka (2000), which points out regional differences in the state of research, provides a valuable insight into the influence of archeological Neolithic cultures on changes of landscape.

\section{GIS analysis of changes of landscape structure}

Geographic Information Systems is type of a research platform combining natural sciences and humanities which applies achievements of geoinformation technologies. According to I. Gregory et al. (2014, pp. 10-11) the term "GIS is used in relation to tools (software)", while the term geo-informatics is understood more widely as a "science of development and application of such tools". As a result of a dynamic development of this area it is possible to analyze spatial phenomena with the attribute of 
time. The subject of research of historical GIS is therefore the issue of changes in time and space, connected to analyses of changes in land use and recreation of historical landscapes based on old maps or data retrieved from archeological research and written sources. Analysis of landscape dynamics is conducted in GIS through a juxtaposition of maps coming from different historical periods, which in turn makes it possible to grasp changes in classes of land cover and land use. The most problematic issue is map mathematical basics of such elaborations, understood as "conformity of distance, angles and areas to their actual values" (J. Wolski 2012, p. 20). These problems refer to the type of used projection, system of reference and correctness of the presented situation.

Calibration of historical cartographic sources is an important issue. Determining georeference is necessary because of low precision of old measurements, in which angles, distances and scale are distorted to a certain extent. Map calibration is performed through control points which are entered into the old map sheet and linked to modern geodetic network. Helmert's transformation and affine transformation, which are most often used in the process of calibration, consist of a shift, turn and change of scale of the initial setup. In the case of the affine transformation also the inclination of objects is altered. Correct placement of control points (possibly evenly) affects the quality of calibration, which can be verified by RMSE error. RMSE "gives information about an average value of deviation of all points expressed in the units of the map, thanks to which we obtain information about the level of inaccuracy of fitting of the whole sheet" (J. Kuna 2015, p. 134).

Analysis of land use forms plays a major role, since "the term directly linked to land cover is land use, reflecting the objectives of human exploitation of a given type of land cover" (K. Ostapowicz 2012, p. 1). All changes in the structure of landscape are connected to the presence of anthropogenic forms (e.g. buildings or roads) and changes of land use, e.g. deforestation of slopes for agriculture. The first attempts to cartographically grasp anthropogenic changes in the analyzed area were made in 1990s. The research involved modeling of changes performed on a small fragment of the area. "Changes of use for the periods of 1973-1983 and 1983-1996 were determined by overlaying vector layers of land use data from particular years" (E. Nowocień et al. 2003, p. 76). The analysis of land cover on the part of the analyzed area (the basin of Grodarz brook) with particular attention paid to surface flow was performed by the team from the Institute of Soil Science and Plant Cultivation (IUNG) in Puławy. The analysis presented in the article is therefore the first comprehensive take of the research problem in the area of Kazimierski Landscape Park.

\section{Characteristics of the area of research}

The spatial range of the analysis covers the terrain of Kazimierski Landscape Park, which was founded on 27 April 1979 as a part of the project of the Department of Nature Conservation of the Polish Academy of Sciences in Cracow. It is located in the mega-region of Beyond-Alps Central Europe, the province of Polish Uplands, sub-province of Lublin-Lviv Upland, macroregion of Lublin Upland. Within the park there are four geologically different mesoregions: Nałęczów Plateau, Bełżyce Plain, Chodelka Hollow and Małopolska Gap of the Vistula (J. Solon et al. 2018). they are built of , i.a. maastrichtian rocks (Upper Cretaceous): bedrocks, marls, limestone and gaizes. From the period of Paleocene there appear sands and sandstones, while during Oligocene sandclay and sand-gravel deposits were sedimentated. The most visible mark on the analyzed landscape was left by the Pleistocene eolic accumulation of loess dust, as a result of which over 70 thousand years the layer of loess reached the thickness of up to 25 meters. The Vistula flowing through the western part of the researched area provides a local erosion base. Almost all the area of Nałęczów Plateau with its complicated ravine systems belongs to the basin of Bystra, the valley of which determines the axis of the Plateau.

Brown earths and luvisols, particularly rich in humus, which appear on the base of loess, could have been the factor which made this region attractive for first farmers. Despite being a part of Lubelska Upland, the mesoregions of Bełżyce Plain and Nałęczów Plateau are significantly different both in their physical-geographical conditions and in the intensity of settlement processes. The earliest traces of 
human activity in the area date back to the Upper Paleolithic (13,000 B.C.E.). However, the first traces of permanent settlements within the researched mesoregions come from the late 6 th century B.C.E. Settlement preferences of prehistoric communities became visible here, since Bełżyce Plain was void of settlement in comparison to Nałęczów Plateau, only sporadically penetrated by Neolithic communities, because of its less fertile podzol soils, which were more difficult to cultivate.

Expansion of settlement in the middle Neolithic covered the hilltops of Nałęczów Plateau. At that time extensively cultivated fields were subsequently rotated after becoming infertile. Thus the settlement network of that period is seemingly well developed. However, the initiation of first transformations of plateau areas is evident in inflow cones analyzed in the valley of Bystra, which are dated back to the middle Neolithic. In the Bronze Age in the area there appeared cultural units characterized by pastoral economic strategy. In the Iron Age the settlement recessed and gave way to common reforestation. Therefore permanent development of river valleys took place only in the early Middle Ages. At that time the settlement network concentrated in the vicinity of rivers and streams, while economic activity occupied the area of hilltops. Demographic pressure in the mid-13th century resulted in the expansion of settlement processes into hilltop areas. Further development and maximization of profits from agriculture - in the form of exporting crops from granges and large area farms of the nobility down the navigable Vistula - led to a deforestation in the 17th century, which can be indirectly concluded from the volume of grain transported through the port in Stężyca. At the time a transportation network developed connecting the cultivated areas with the valley of the navigable Vistula. It resulted in a dense network of road ravines which is used to transport crops from the hilltops until today.

\section{Research methods}

The research method consists of five stages (fig. 1). The first of them is the elaboration of the historical objects database basing on the archives of the National Heritage Board of Poland. The second is the calibration of data used in the analysis of old maps and the eval- uation of the performed georeferencing. Next - vectorization of the classes of land cover basing on calibrated old maps. The last stage is the design of maps presenting changes of land use and maps reconstructing the development of the settlement network.

\subsection{Input data}

Research of K. Ostafin (2009) was valuable for the selection of archive data, raster data and vector data. The author presented possibilities of using and verifying historical cartographical sources in geographic research. Methods of analysis of old maps presented in the publication provided an example of the use of the following data:

- archive data "Archeological Survey of Poland" (ASP) - obtained from the National Heritage Board of Poland in the form of 10 sheets of calibrated archive maps with "Cards of Evidence of Archeological Sites", identified in 1980 s and 1990s. The most recent verification research conducted by $Ł$. Miechowicz in 2016 was used for the evaluation of 3 out of 10 sheets.

- registry data „Atlas Fontium” - gathered within the project of elaboration and publication of historical sources and cartographic materials from the area of the pre-partitioning Republic of Poland. "Corona Regni Poloniae" cartographic elaboration at 1:250,000, published by the Institute of History of the Polish Academy of Sciences was used. The elaborated sheet comes from S. Wojciechowski's "Lublin voivodship in the second half of the 16th century" from 1966. The map was prepared on the basis of source data in the form of draft registries (registry of tax for war purposes) which also contained ownership conditions.

-1st Military Topographic Survey of Western Galicia from 1804 - a topographic map published in 1808 at $1: 172,800$, basing on the topographic survey done at 1801-1804 at the 1:28,000 scale prepared by A.M. von Heldensfeld. The cartographic survey of the analyzed area was done just before significant economic and social changes of the 19th century and the reform of agrarian relations. On the one hand the map is characterized by a relatively high level of measurement errors resulting from the lack of properly used triangulation, but on the other hand it presents exceptionally rich natural contents. 


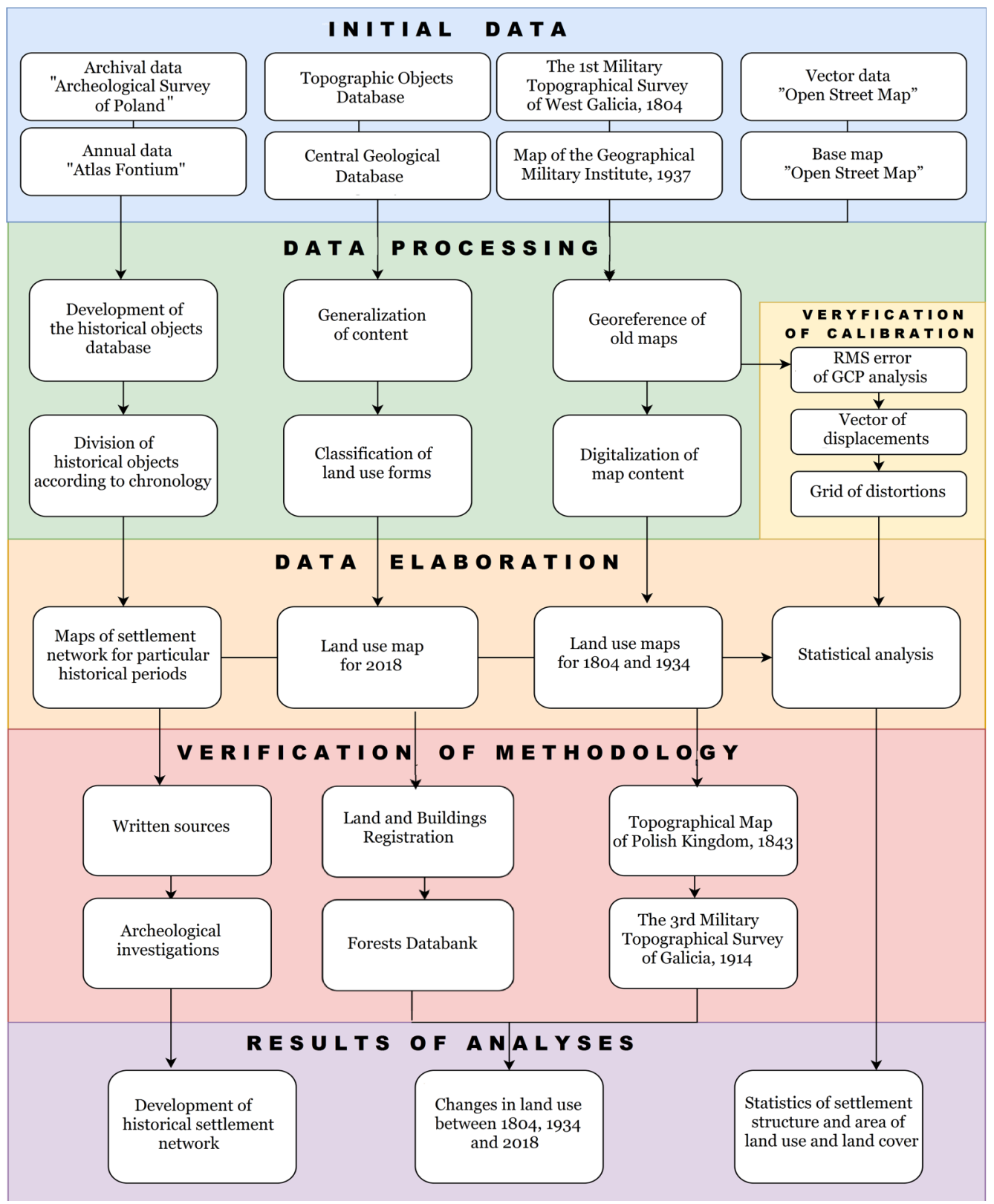

Fig. 1. Scheme of the research method (authors' original work)

- Map of the Military Geographical institute from 1937 - a topographic map at 1:100,000 is a cartographic work prepared on the basis of detailed maps of Poland at the 1:25,000 scale.
It was published in the period between the World Wars in the form of 482 sheets.

- Topographic Objects Database (BDOT10k), with the level of detail related to maps at the 
$1: 10,000$, as defined in the "Decree of the Minister of Interior and Administration of 17 November 2011 referring to the database of topographic objects and the database of general geographic objects, as well as standard cartographic works". It was prepared in the "1992" coordinate system.

- "OpenStreetMap" data - spatial data distributed with open license and verified by users of "Open Source" materials. Using them as the reference material in the process of calibration was determined by the MapAnalyst software used at the stage of verification of the performed geo-referencing. Additionally, the existing plug-ins, or additional tools which can be downloaded, allow for the use of OSM as the base map without the need to download vector data.

\subsection{Designing the structure of the historical objects database}

Elaboration of the database containing information on the structure of settlement was done in ArcMap 10 program. The source of data for the designed database were Record Cards of Archeological Monuments, thanks to which sites from 10 sheets of calibrated Archeological Survey of Poland maps were identified. The total number of sites in the analyzed area amounted to 315. Placement of many historical objects of different chronology and cultural assignment at the same location (so-called multi-phase objects) was problematic. The analysis accounted separately for each phase of settlement in order to avoid the error of omitting data.

\subsection{Calibration of old maps and its evaluation}

For the analysis of changes in land use old maps were used. Basing on them, the classes of land cover of that time were vectorized. In order to perform georeferencing not based on Heldensfeld's geodetic network, 10 control points were evenly placed on the map. Most of them were intersections of transportation routes and churches. Spline transformation was applied, and the measured RMSE error was approx. $100 \mathrm{~m}$. To the second old map used - WIG tactical map, because of its mathematical basics, affine transformation was applied by fitting data in the historical coordinate system into the frame (quasi-stereographic conformal projection, Bessel's ellipsoids from 1841). Four control points in sheet corners with geographic coordinates were used for calibration. Evaluation of the performed calibration was done through the analysis of geometric distortion in MapAnalyst software, in which distortion nets and displacement vectors were created.

\subsection{Vectorization and classification of the forms of land cover and use}

On calibrated maps selected forms of land cover and land use were vectorized. The resulting classes from the map of Western Galicia refer to the performed vectorization of the WIG tactical map from 1937, in which hydrographic network, cultivated land and meadows, forests, transportation and settlement network were also marked. Within the class of transportation network the old division of roads into main roads, ducts, collecting roads and local roads, conforming to the older Heifdensfeld's map, was preserved. Buildings were classified similarly, marking commercial facilities such as mills and sawmills. Various scales of maps required not only generalization but also more detailed analysis in order to compare different materials.

\subsection{Generalization of the Topographic Objects Database}

Topographic Objects Database at the level of detail corresponding to maps at 1:10,000 scale provided rich contents and developed system of classification of the forms of land cover and land use. Data obtained from the resources of the Head Office of Geodesy and Cartography underwent a process of generalization, the aim of which was to select layers necessary for the elaboration of maps of land use. From 9 classes of BDOT10k topographic objects, i.a. water network, transportation network, land cover, buildings, the classes necessary for elaboration of maps of land use were selected, such as e.g. surface waters or wooded areas.

\section{Research results}

Results of the analysis constitute two sets of maps presenting settlement network and land use evolution. Maps of the settlement network 
chronologically cover the range from the Stone Ages (Paleolithic, Mesolithic, Neolithic), through the Bronze Age, Iron Age, Early Middle Age to the Late Middle Age (fig. 2). Structure of the settlement network elaborated for particular historical epochs seems to correlate with the taries, while for the shepherd spherical amphora culture there were 7 campsites and 1 cemetary. Spatial analysis of archeological sites showed a great variety in the scale of anthropopressure and in the intensity of settlement changes over time.

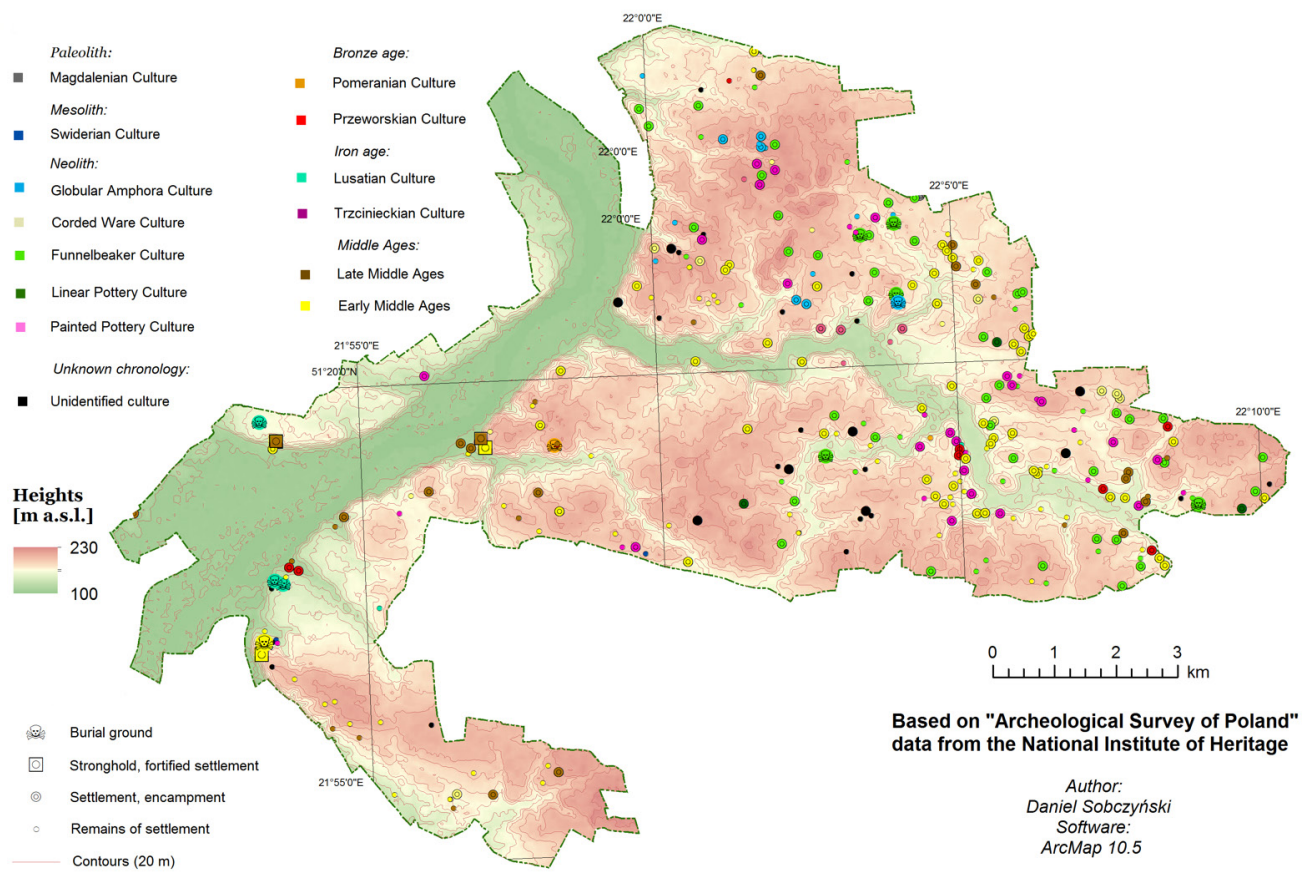

Fig. 2. Historical settlement network in the Kazimierski Landscape Park

settlement preferences of particular archeological cultures. They are especially evident in the Bystra basin in the Eastern part of Kazimierski Landscape Park. The historical objects database was visualized including the function of particular objects. The resulting cartographic visualization contains layers presenting the location of archeological sites, their structure and cultural affiliation against the background of a hypsometric map.

As a result of the analysis of the Archeological Survey of Poland archive it was established that in the Stone Age subsequent cultures were characterized by varied structure of settlement. For example, for the agricultural funnelbeaker culture there were 57 settlements and 5 ceme-
An attempt to determine the dynamics of changes resulted in a statistical identification of changes of spatial shares of particular forms of land use in the analyzed chronological range (figs. 6-9). Distribution of the forms of land use echoes historical events, political decisions and applied economic strategy. The second set of visualized results of the analysis comprises maps presenting the state of environment starting from 16th century until 2018. Maps of land use from 1801-1804, 1934 and 2018 are based on very valuable cartographic sources (fig. 3-5). Historical sources in the form of tax registers were also considered; they show a settlement situation different from that of today -2 towns and 23 villages. Later maps 


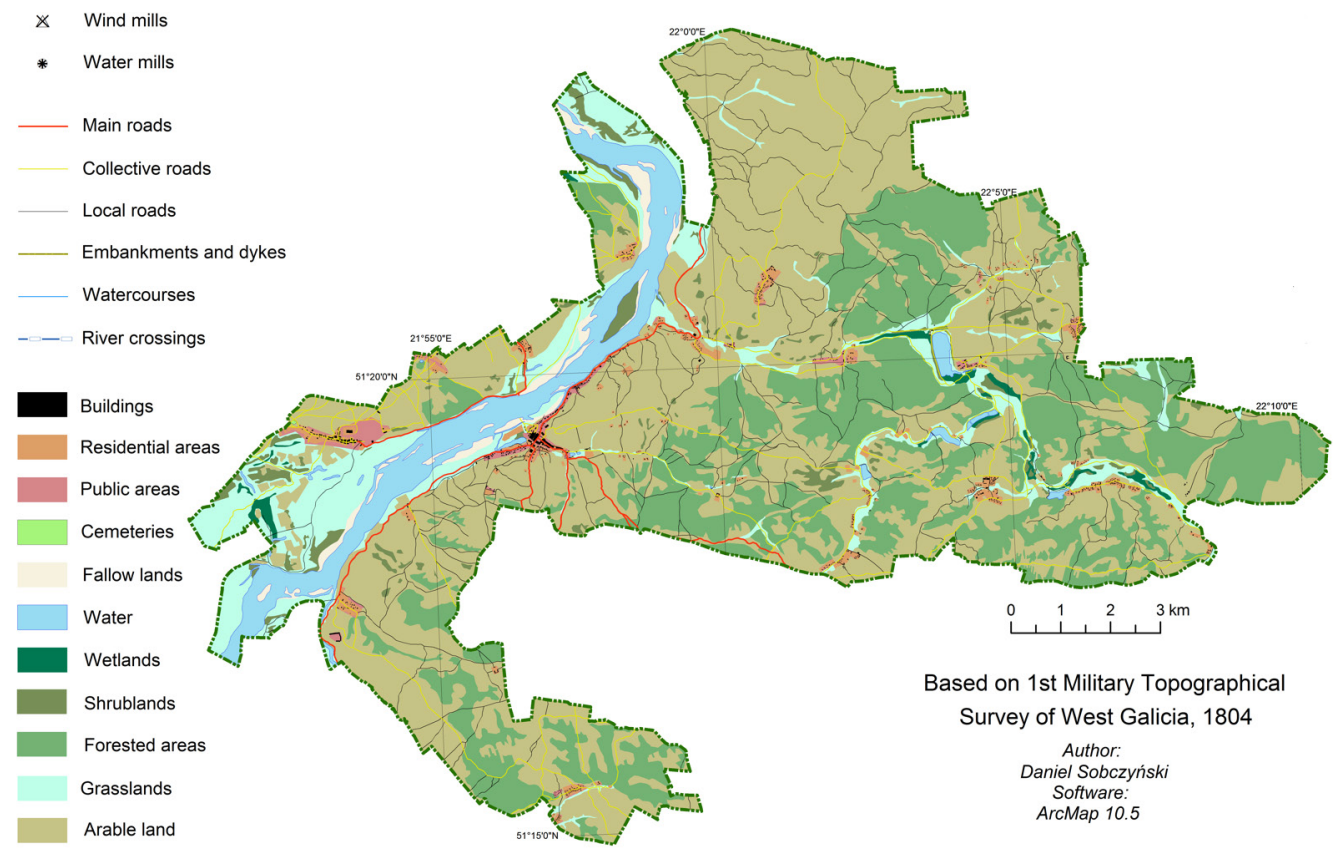

Fig. 3. Land use in the Kazimierski Landscape Park 1804

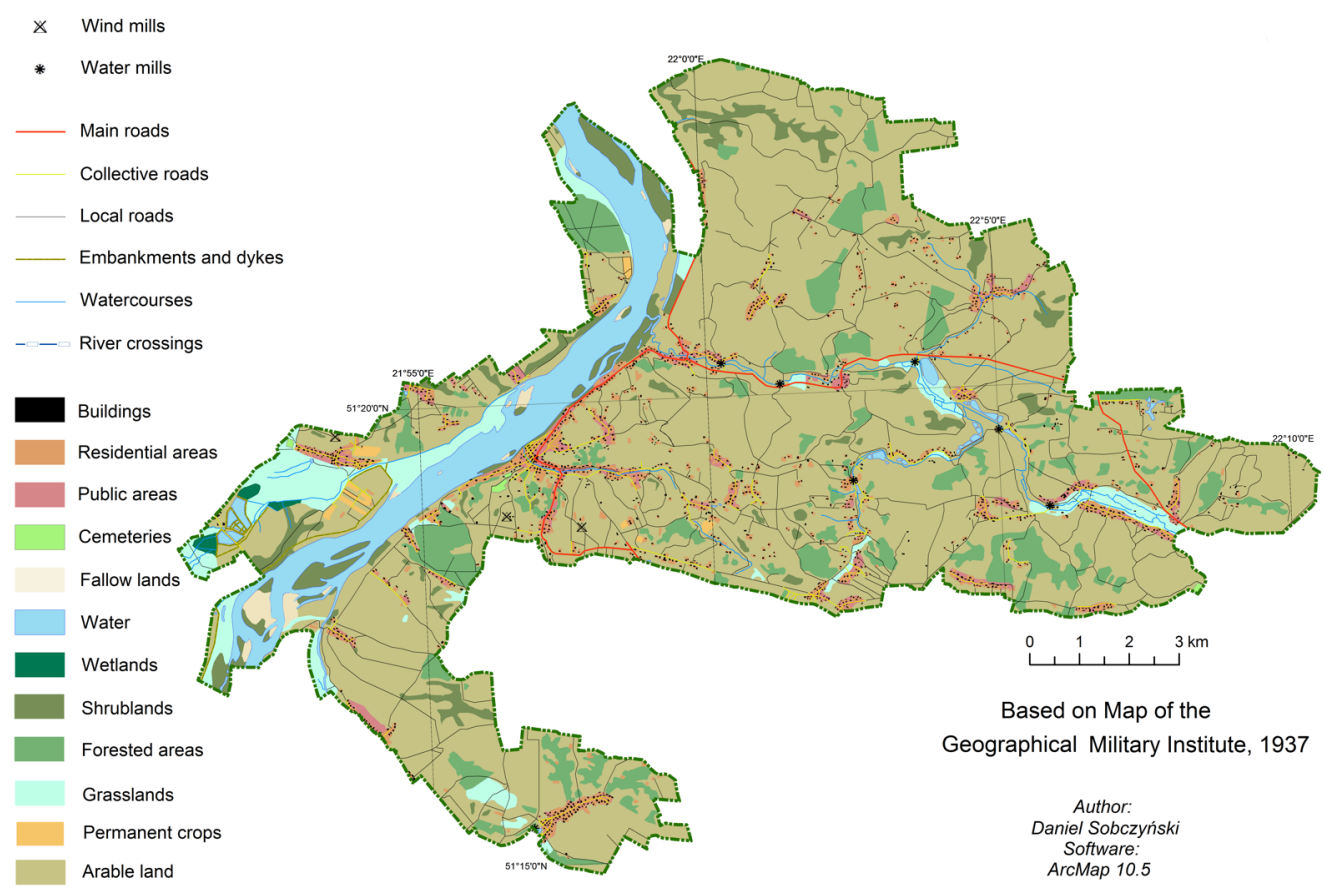

Fig. 4. Land use in the Kazimierski Landscape Park 1937 


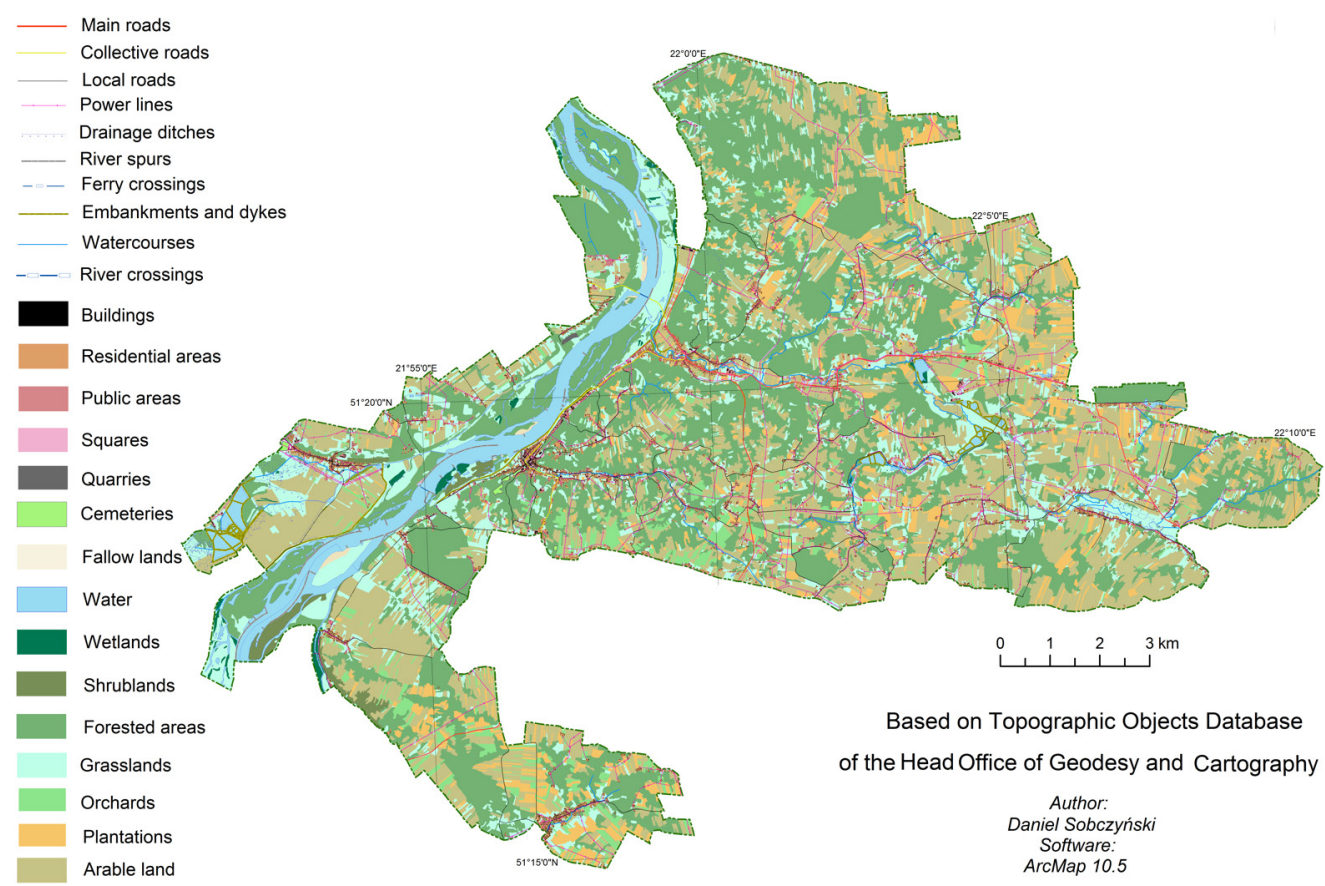

Fig. 5. Land use in the Kazimierski Landscape Park 2018

from 19th century present 2 towns and 26 villages, while today it is 1 town and 16 villages. The map based on the data from the Institute of History of the Polish Academy of Sciences presenting the settlement network in the 16th century is an exception. The settlement structure it presents consists of towns and villages distinguished by their ownership: belonging to

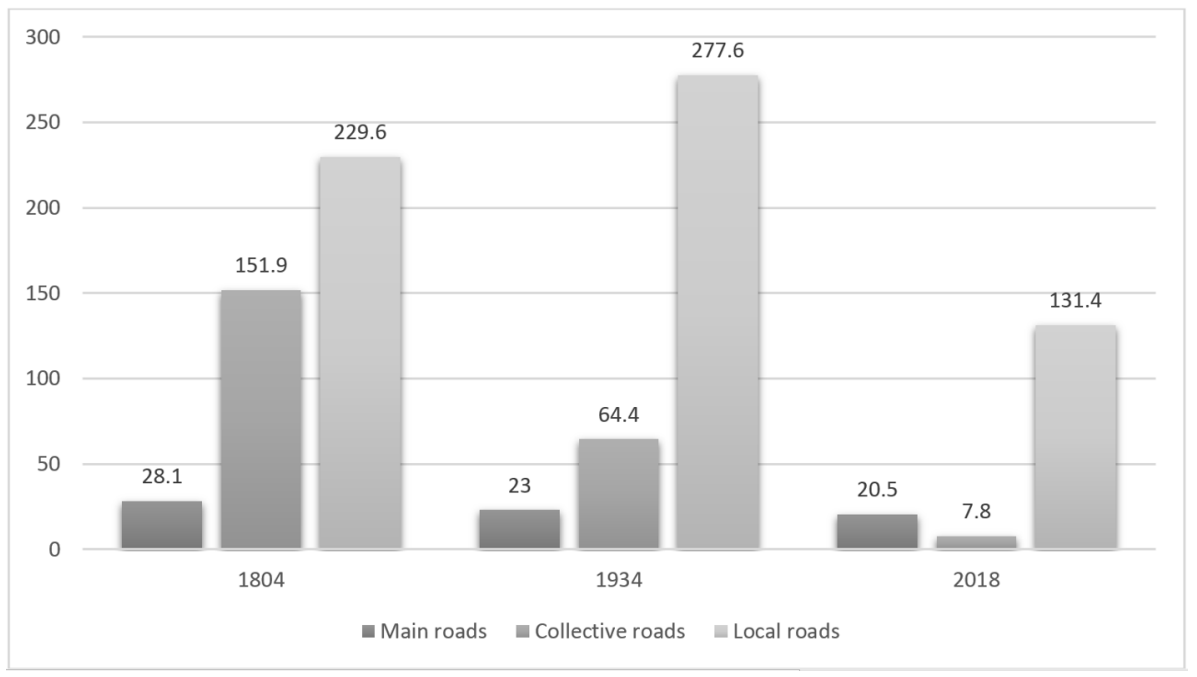

Fig. 6. Development of road network 1804-2018 (in kilometers) 


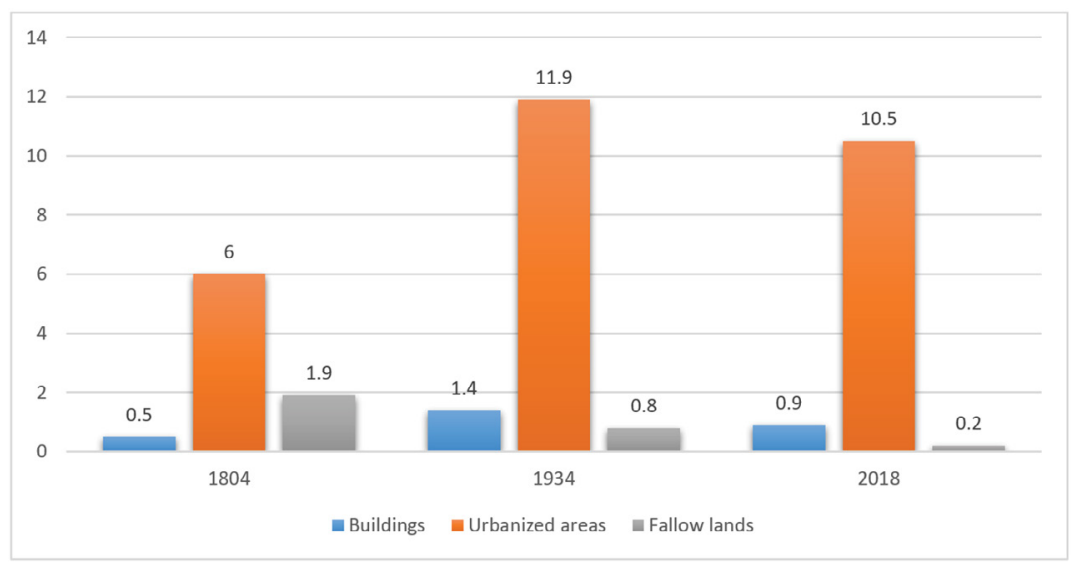

Fig. 7. Changes in surface of usable areas 1804-2018 (in square kilometers)

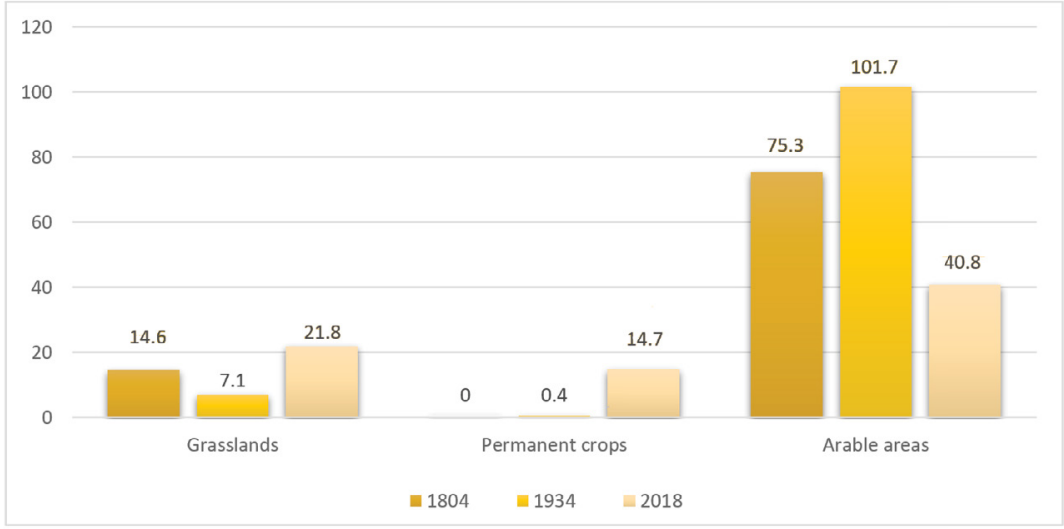

Fig. 8. Changes in arable land area 1804-2018 (in square kilometers)

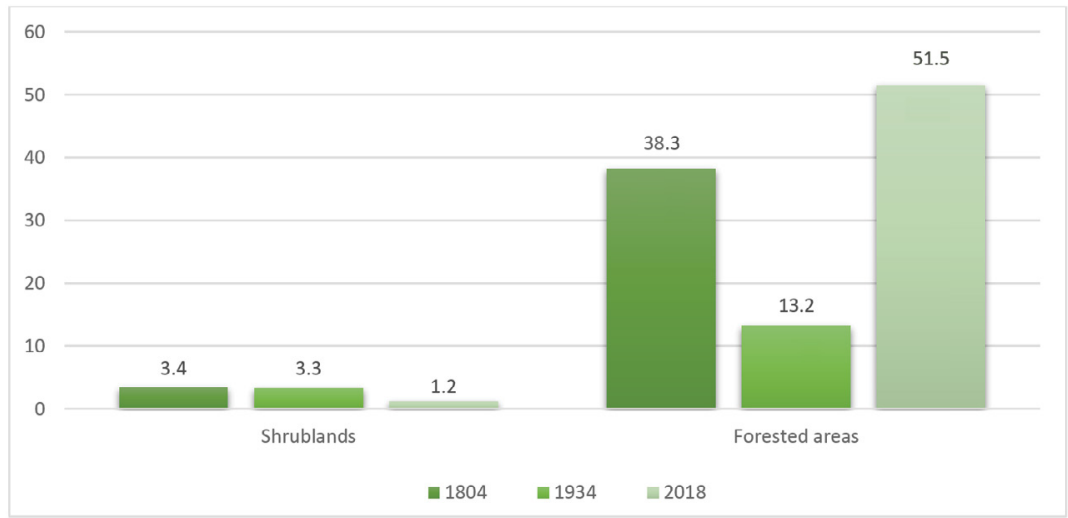

Fig. 9. Changes in surface of forest areas 1804-2018 (in square kilometers) 
the king, the nobility or the church. The map also provides very valuable information about transportation routes.
Regression of settlement processes observed in the last century concerns also transportation routes and the size of anthropogenic areas. In

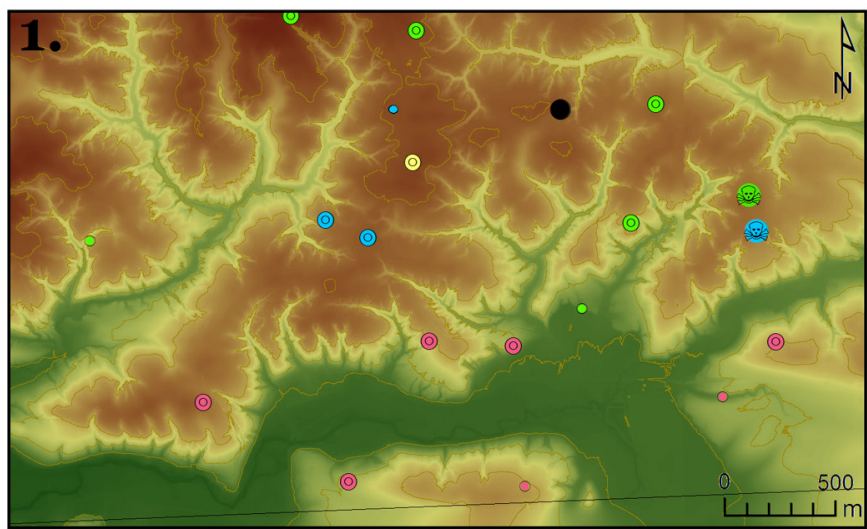

1. Neolith

2. Iron age

3. Early Middle Ages

Burial ground

(9) Settlement, encampment

- Remains of settlement Contours $(20 \mathrm{~m})$

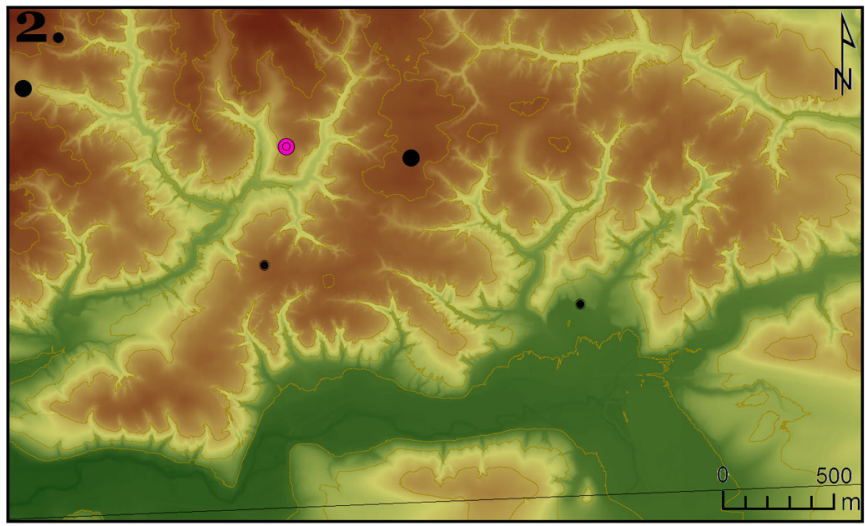

Neolith:

- Globular Amphora Culture

Corded Ware Culture

- Funnelbeaker Culture

- Painted Pottery Culture Iron age.

- Trzcinieckian Culture

- Unidentified culture Middle Ages:

Early Middle Ages

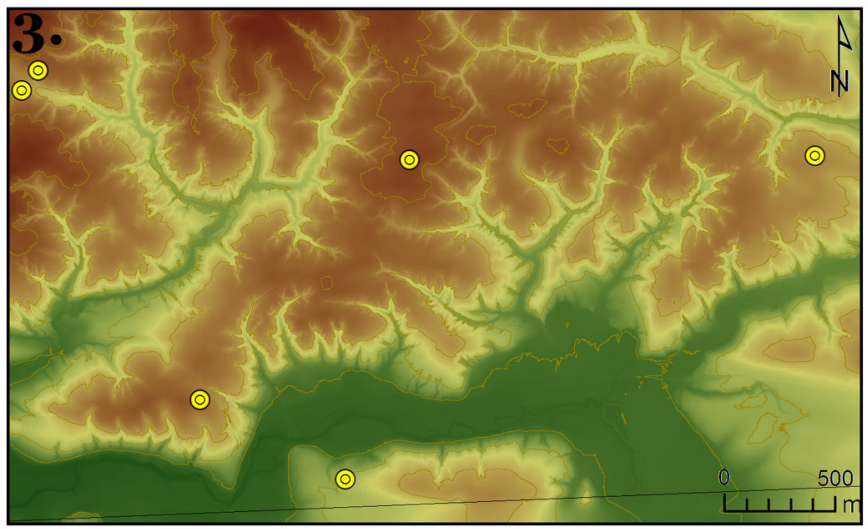

Heights [m a.s.1.]

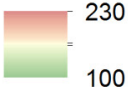

Based on "Archeological Survey of Poland" (The National Heritage Board of Poland) and altitude data (The Head Office of Geodesy and Cartography)

Author: Daniel Sobczyński Software: ArcMap 10.5

Fig. 10. Historical settlement network in the environs of Las Stocki 
the last 200 years the network of main roads has shrunk by $27 \%$, and of local roads by $43 \%$. Despite a traditionally agricultural character of the region, from mid-19th century an increasing share of urbanized areas can be observed until the foundation of Kazimierski Landscape Park in the 1970s. Sudden decrease in the size of cultivated area, which had been increasing earlier, was observed. In 1934 it occupied $67,9 \%$ of the total area and by 2018 it was reduced to $27,3 \%$, replaced partly by permanent crops, i.a. orchards and plantations. Dynamic changes took place in wooded areas in the analyzed area. The culmination of many centuries of tree felling took place in 1934, when forests occupied only $8,8 \%$ of the total area. Currently their area reached $34,4 \%$ and is still growing, contrary to shrubs and surface waters of the Vistula.

\section{Analysis and discussion of research results}

Results of the analysis conform to the outcome of archaeological, sedimentological and geomorphological research. Additionally, the performed analyses of cartographical resources show similar tendencies in development of the forms of land use as the research conducted in the 20th and 21st centuries.

Extensive economy of the Neolithic funnelbeaker culture probably locally initiated ravine erosion in Kazimierski Landcape Park by applying slash and burn technique on loess hilltops (fig. 10). Later an abrupt decrease of the number of sites was observed together with a change of their character from permanent settlements to temporary campsites. In the Bronze and Iron Ages a tendency was observed to concentrate settlement in settlement microregions. The settlement network of the tribal phase was located in valleys, while hilltops were exploited economically. Demographic potential of that time together with new technological capabilities resulted in a second deforestation, this time permanent. Dating of sediments obtained by J. Reder (2010) shows that such forms as road ravines developed during the time of the state of Piasts, which is confirmed by a thicker anthropogenic fen soil in that period. Results of A. Rozwałka's research (1999) show, that a thick settlement network developed in the region as a consequence of stabilization of the Kingdom of Poland. Spreading of a dense ecumena in the Middle Ages probably occurred from settlement microregions in river valleys to economically exploited loess hilltops. Introduction of grange economy in the 16 th and 17 th centuries brought about a radical change - it led to deforestation of loess areas located in the vicinity of the Vistula, which at that time acted as a trade route through which grain and timber were transported. Geomorphological and archeological research conducted in the sections of ravine systems seems to confirm the rapid development of the transportation network at that time, which was evident in the analysis. Through the presence of linear forms in loess landscape water erosion which models terrain relief becomes stronger. Mono-culture of grains exported to Western markets added to the pace of surface flow which modeled the landscape. This process reached its high point in modern times as a result of the growing demographic pressure and mechanization of agriculture.

Sheets of Heldensfeld's map from 1808 used for the analysis showed the state of spatial development of the analyzed area just before the transformation of settlements related to the abolition of serfdom and introduction of sanitary regulations. Also the tactical WIG map from 1937 provided an excellent source of information about the state of land use from before the era of rapid industrialization and large scale drainage of the land of Poland. At the same time, the map of land use for the year 2018 elaborated with BDOT10k generalization shows a distinct mosaic of forms and their complex distribution (fig. 11). This results, on the one hand, from fragmentation of land common in the area, and on the other hand from the highest level of detail of input data in comparison to all the other used maps. Analysis of changes in land use performed on the basis of cartographically documented historical sources also accounts for the data from the Registry of Land and Buildings as well as the Data Bank of Wooded Areas for the purpose of verification of its conclusions.

\section{Conclusions}

Application of the Geographical Information Systems' tools in this paper confirmed a high analytical potential of the GIS environment in processing of varied input data, at the same time enabling a broad insight into the research issue. Spatial relations invisible in the archive 
of Archeological Survey of Poland could be proven this way. The elaborated historical objects database is an example of the potential of digital documentation of cultural heritage within the frame of building the infrastructure of spatial information. Verification of collected data demonstrated the variety of the scale of anthropopressure depending on the historical

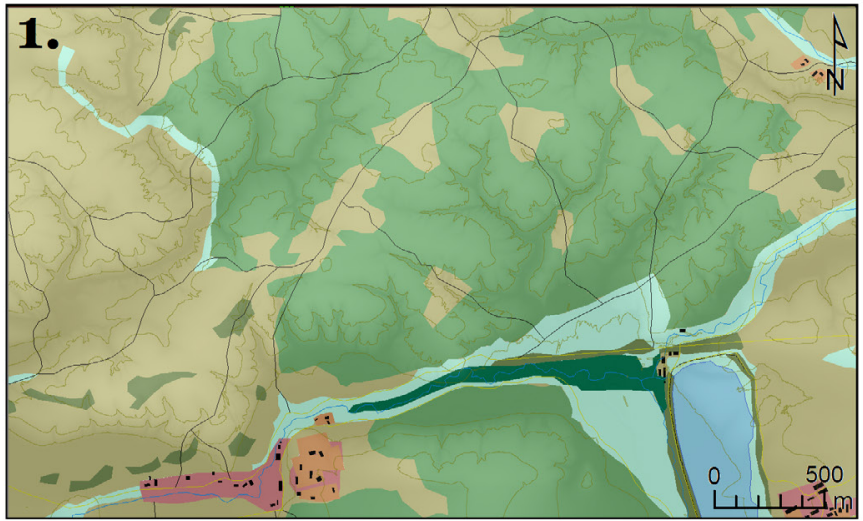

1. State as of 1804

2. State as of 1937

3. State as of 2018

Main roads

Collective roads

Local roads

Watercourses

Contours $(20 \mathrm{~m})$

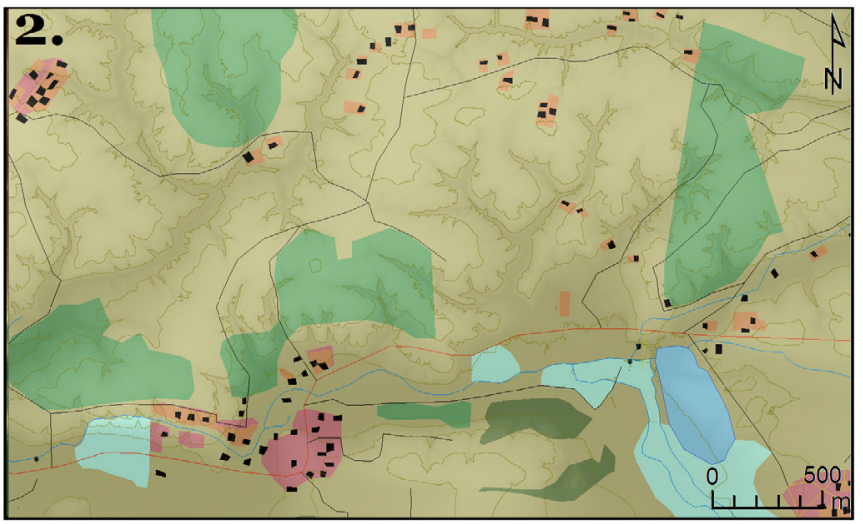

\begin{tabular}{|l|l|}
\hline Buildings \\
\hline Residential areas \\
\hline Public areas \\
Squares \\
Quarries \\
\hline Cemeteries \\
Fallow lands \\
\hline Water \\
\hline Wetlands \\
Shrublands \\
Forested areas \\
Grasslands \\
Orchards \\
Plantations \\
Arable lands
\end{tabular}

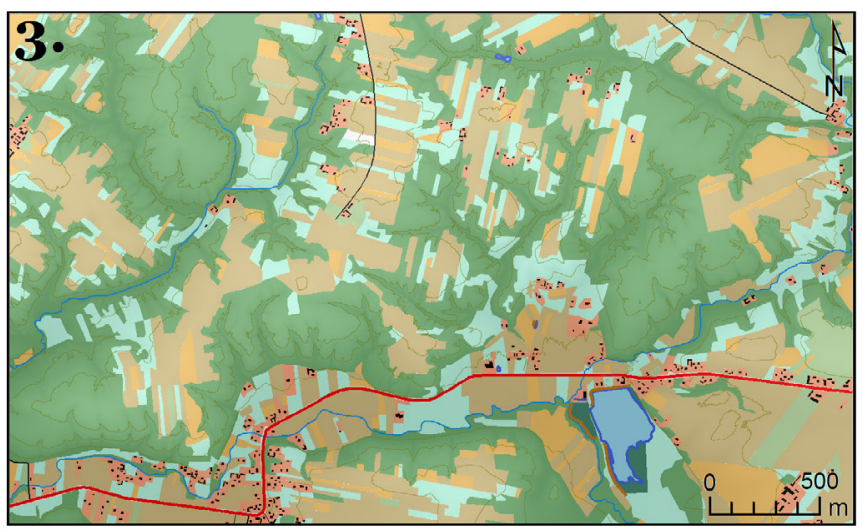

Based on Topographic Objects Database and altitude data (the Head Office of Geodesy and Cartography)

Author: Daniel Sobczyński Software: ArcMap 10.5

Fig. 11. Land use in the environs of Las Stocki 
period. Uncertainty of historical data and its scarcity in comparison to later cartographic material remained problematic. Therefore the map of settlement network and land use in Kazimierski Landscape Park (in 16th century), because of its estimative character, was not included in the statistical analysis. On the other hand, such data enriched the analysis with the structure of ownership of particular settlements and the location of transportation routes in the Middle Ages. Data obtained as a result of vectorization of the contents of calibrated maps made it possible to recreate further sequence of development of the network of settlement thanks to the information concerning i.a. location of buildings and the range of built-up area. Additionally, the accuracy of cartographic elaborations enabled a reconstruction of changes in the transportation network and its structure, which after verification showed convergence of their location with erosion forms.

\section{Literature}

Gregory I., Geddes A., 2014, Toward spatial humanities: Historical GIS and spatial history. Series "The Spatial Humanities", Indiana University Press, pp. 10-11.

Kukawka S., 2000, Zaludnienie i zmiany środowiska naturalnego w neolicie wyżyn lessowych (uwagi krytyczne). "Archeologia Polski” T. 15, pp. 99-109.

Kuna J., 2015, Metodyczne aspekty analiz przestrzennych GIS wykorzystujących dawne mapy topograficzne. In: Dawne mapy topograficzne w badaniach geograficzno-historycznych, ed. A. Czerny. Lublin: Uniwersytet Marii Curie-Skłodowskiej, pp. 125-150.

Myga-Piątek U., 2001, Spór o pojęcie krajobrazu w geografii $i$ dziedzinach pokrewnych. "Przegląd Geograficzny” T. 73, z. 1-2, pp. 163-176.

Myga-Piątek U., 2012, Krajobrazy kulturowe. Aspekty ewolucyjne $i$ typologiczne. Katowice: Uniwersytet Śląski.

Nowocień E., Podolski B., Wawer R., 2003, Zmiany użytkowania gruntów zlewni potoku Grodarz z wykorzystaniem ortofotomap lotniczych i GIS na podstawie wieloletniego monitoringu. "Regionalny Monitoring Środowiska Przyrodniczego" Nr 4, Kielce: Kieleckie Towarzystwo Naukowe, pp. 75-78.

Ostafin K., 2009, Zmiany granicy rolno-leśnej w środkowej części Beskidu Średniego od połowy XIX wieku do 2005 roku, Kraków: Wydawnictwo Uniwersytetu Jagiellońskiego.
The performed analysis concerning land use structure changes, resulted in the necessity of cartographic presentation methods and old map's mathematical basics evaluation. The analysis of old maps' distortion confirmed the selection of a proper method of transformation during the calibration of a Heldensfeld's map (rubbersheeting transformation) and of a WIG tactical map (affine transformation). The advantage of the elaborated maps of land use over former research concerning the analyzed area is in their spatial and time range. Dynamics of landscape changes were especially stressed in the processing of statistical data. Conducted research confirms that geoinformatic methods of analysis of natural phenomena allow for a presentation of a more complete picture of processes occuring in the natural environment, and that application of Geographic Information Systems enables effective monitoring of changes.

Ostapowicz K., 2012, Modelowanie przestrzenne zmian pokrycia terenu. In: Zastosowania metod statystycznych $w$ badaniach naukowych, Vol. 4, Kraków, 175 pp.

Ostaszewska K., Heinrich J., Schmidt R., Krüger A., 2011, Użytkowanie ziemi jako czynnik krajobrazotwórczy na obszarach lessowych. "Prace i Studia Geograficzne" T. 46, pp. 63-76.

Plit J., 2016, Krajobrazy kulturowe Polski i ich przemiany. "Prace Geograficzne" Nr 253, Warszawa: Instytut Geografii i Przestrzennego Zagospodarowania PAN, 302 pp.

Reder J., Superson J., Król T., 2010, Etapy rozwoju osadnictwa zachodniej części Płaskowyżu Nałęczowskiego i ich zapis w osadach dna doliny Bystrej. "Annales Universitatis Paedagogicae Cracoviensis, Studia Geographica" 1, pp. 127-130.

Rozwałka A., 1999, Sieć osadnicza w archidiakonacie lubelskim w średniowieczu. Studium archeologiczno-historyczne Lublin: Wydawnictwo UMCS, 218 pp.

Solon J. et al., 2018, Physico-geographical mesoregions of Poland: Verification and adjustment of boundaries on the basis of contemporary spatial data. “Geographia Polonica” Vol. 91, issue 2, pp. 143-169.

Wolski J., 2012, Błędy i niepewność w procesie tworzenia map numerycznych. In: Źródła kartograficzne w badaniach krajobrazu kulturowego. Sosnowiec: Komisja Krajobrazu Kulturowego Polskiego Towarzystwa Geograficznego. 